\title{
Research on Development and Prospects of Chinese-Foreign Cooperation in Running Schools in the "New Era"
}

\author{
Qian Zeng * \\ International Cooperation \& Exchange Office \\ Yunnan University of Finance and Economics, YUFE \\ Kunming, China \\ bmwii@foxmail.com
}

\author{
Hongmin Li \\ International Cooperation \& Exchange Office \\ Yunnan University of Finance and Economics, YUFE \\ Kunming, China \\ bizlynn@hotmail.com
}

\author{
Zhifei Li \\ International Cooperation \& Exchange Office \\ Yunnan University of Finance and Economics, YUFE \\ Kunming, China \\ lizhifei1115@126.com
}

\begin{abstract}
After nearly 30 years of development, the ChineseForeign Cooperation in Running Schools (CFCRS) has become an indispensable part of Chinese higher education and a unique way to boost the higher education internationalization. Now the government, institutes of higher education and society are asking the same question: how CFCRS can contribute for the implementation of "Double World-Classes" strategy and Educational Opening-up policy in the "New Era". By trace the development path and current situation of CFCRS in terms of its approval system, scales, social recognition and policy environment, this article predicts the development trend and provide some practical suggestions for CFCRS. In the New Era, the key development strategy will focus on two aspects: rebalance and competitiveness. The specific steps include readjusting the development pace and optimizing the structure, as well as encouraging Chinese universities to find prestigious foreign universities as their partner or highlight the uniqueness of the cooperation.
\end{abstract}

Keywords-Chinese-Foreign Cooperation in Running Schools; New Era; Current situation; Prospects

In the 19th National Congress of the Communist Party of China, General Secretary Xi Jinping, for the first time, presented a new historical development course for China: Socialism with Chinese characteristics in the New Era. After his speech, the phrase "New Era" has been given fresh meaning and interpretation in the field of humanistic and social science. In the New Era, CFCRS has become an indispensable and influential part of higher education internationalization in China after nearly 30 years of development. It also drawn much attention from the governments and scholars home and aboard. This article will analyze the status quo and future challenges of CFCRS first, and then provide some constructive suggestions for sustainable development of CFCRS based in the New Era.

Supported by the Youth Research Project of Yunnan University of Finance and Economics (Grant No.80059900164)

\section{THE BACKGROUND OF "NEW ERA"}

For now and the following decades, China is entering into the New Era. During this period, China will focus on domestic transformation and accelerate the opening-up to the outside world. With the further economic reforms and industrial restructuring, especially the implementation of "Made in China 2025" strategy, China is becoming stronger and more important in the world economic cooperation. Benefited from the regional cooperative platforms, such as 'Belt and Road initiative' and Shanghai Cooperation Organization, China has increased its capacity of participating in the global governance.

In regard to education, Chinese people and government always regard it as the foundation of a nation and the driving force for sustainable development. Therefore, in the background of New Era, which direction shall the higher education internationalization of China go? What will be the ultimate goal of CFCRS and which path shall it follow? All these questions are waiting to be answered. At the dawn of the New Era, Chinese government has issued three guiding official documents to steer the course of higher education internationalization (referring to TABLE I). The above three documents all directly or indirectly mentioned CFCRS and outlined the requirements at macro level; therefore they are the guidelines for the future development of CFCRS.

Among these three guiding documents, the first one, which was issued in 2015, did not mention CFCRS in its contents directly. However, it did emphasize the importance of bringing in high-quality foreign educational resources to support the "World-Class Universities and First-class Disciplines" strategy. The essential goal of CFCRS is perfectly matching this requirement. Both the second and third documents have mentioned quality control as the priority target for CFCRS future development. Besides, they also required education administrative authorities to improve the management systems 
and coordinate the development. These three documents clearly indicate that CFCRS has become an important part of national education strategy in the New Era.

TABLE I. EXPRESSION OF CFCRS IN NATIONAL GUIDING DOCUMENTS

\begin{tabular}{|c|c|c|c|}
\hline Time & Authority & Document & Content \\
\hline $\begin{array}{l}\text { Oct. } \\
2015\end{array}$ & The State Council & $\begin{array}{c}\text { General Plan for Promotion and Construction of } \\
\text { World-Class Universities and First-Class Disciplines }\end{array}$ & $\begin{array}{l}\text { "Enhance the cooperation with world-class universities; } \\
\text { effectively integrate high-quality foreign education elements."[1] }\end{array}$ \\
\hline $\begin{array}{l}\text { Mar. } \\
2016\end{array}$ & $\begin{array}{l}\text { General Office of the CPC } \\
\text { Central Committee } \\
\text { General Office of the State } \\
\text { Council }\end{array}$ & $\begin{array}{l}\text { Certain Opinions for the Opening-up of Education in } \\
\text { the New Era }\end{array}$ & $\begin{array}{l}\text { "Improve management system and mechanism, } \\
\text { Introduce foreign educational resources in discipline of science } \\
\text { and engineering”[2] }\end{array}$ \\
\hline $\begin{array}{c}\text { Jan. } \\
2017\end{array}$ & The State Council & $\begin{array}{l}13^{\text {th }} \text { Five-Year Plan for the Development of National } \\
\text { Education }\end{array}$ & "Improve the quality and management of CFCRS"[3] \\
\hline
\end{tabular}

\section{STATUS QUO OF CFCRS}

\section{A. Institutionalization of approval system}

Since CFCRS is quite special compared with other international education modes, there are more strict rules to follow during its application and approval process. According to the Regulation of P. R. China for Chinese-Foreign Cooperation in Running Schools, the Ministry of Education (MOE) is responsible for the CFCRS's approval and monitory. The annual volume of CFCRS approvals can not only show the growth trend, but also unveil the government's attitude toward CFCRS. Therefore, by collecting and analyzing the recent12 years' number of approvals, we can find the approval system has been put on an institutionalized, normalized and scientific administration track. From 2006 to 2009, MOE almost paused the approval procedures for 4 years and resumed in 2010. Since then, MOE will accept application from universities nationwide once a year. From 2011, MOE standardized the approval mechanism and begin to accept application twice each year. This change shows how the education department at national level adjust and control the growth of CFCRS based on the national policies, domestic social needs and international externalities (Fig. 1).

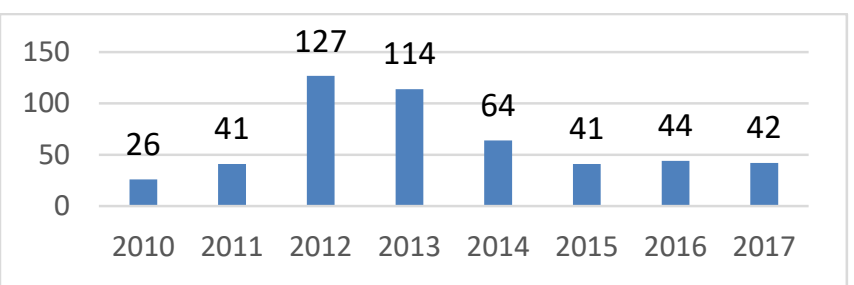

Data resources: http://www.crs.jsj.edu.cn/

Fig. 1. Cfcrs approved by moe from 2010 to 2017

\section{B. Steady growth rate}

With the further implement of Opening-up strategy, CFCRS, as a significant part of the higher education internationalization in China, once experienced a vigorous development period. According to the statistics, by January 2018, China has established 2626 CFCRS institutes and programs involving 34 countries and 1746 universities (785 Chinese and 961 foreign). These institutes and programs cover different education levels from vocational to bachelor, master and $\mathrm{PhD}$ degree, and contain over 200 majors in 12 disciplines. [4] Domestically, most of the key universities have stepped into CFCRS area. As shown in the MOE official website, by March 2018, 36 universities in the "985 project" have established their own CFCRS. Due to policy restrictions, there are only 3 universities in the“ 985 project”, namely the National University of Defense, University of Science and Technology of China as well as Central University for Nationalities, have not establish CFCRS. For the universities in "211 project", there are only 11 out of 112 universities haven't setup their own CFCRS. It means the participation rate for "211 project" universities has reached 90.2\%. Meanwhile, among 137 universities listed in the "World-Class Universities and First-Class Disciplines" project nationwide, 118 universities have participated in CFCRS, which makes the rate as high as $86.1 \%$. [5] Therefore, apart from special cases, the CFCRS has nearly achieved the complete coverage in the top universities nationwide. In the background of improving quality for education internationalization, Chinese universities and education administrative departments will be more rational for the development of CFCRS. Instead of seeing a surge in quantity, CFCRS may enter the stage of steady growth.

\section{Rational thinking of CFCRS development}

As mentioned before, Chinese universities and education administrative departments have reached an agreement on improving the quality and efficacy of CFCRS and try to establish a stable and balanced triangle relationship among the quantity, quality and effectiveness. This relationship should consist of an adequate scale as the foundation, improved quality as the key point and beneficiary effectiveness as the final goal. [6] From the policy level, the national government has illustrated specific requirements for CFCRS quality in several documents. For example, 13th Five-Year Plan for the Development of National Education demands to enhance the quality and management of CFCRS. Opinions for the Opening-up of Education in the New Era, which issued as a programmatic document, ask the universities to import advanced education resources from foreign countries and enhance the quality of CFCRS comprehensively. From the practical level, the education administrative authorities in different provinces have taken various actions. For instance, the Application Guidelines of Chinese-Foreign Cooperation Running Schools issued by Jiangsu province reemphasizes the introduction, assimilation, innovation and promotion of overseas advanced education resources. It also demands local universities with CFCRS to 'support the reform of higher education in Jiangsu province and facilitate the economic development of the nation.' Besides, more universities display great initiative in the quality improvement of CFCRS and pay much attention to the quality assurance system. Upon now, 8 Chinese-Foreign Cooperation Running Institutes have passed 
the International Quality Control Standard, in which, 4 certified by the British Quality Assurance Agency of Higher Education, 2 approved by the French La Commission des titres d'ingénieurs, 1 accredited by the Accreditation, Certification and Quality Assurance Institute (ACQUIN) in Germany and 1 accredited by the Association to Advance Collegiate Schools of Business International (AACSB) in US.[7]

\section{Wide Recognition from society}

At the early stage, CFCRS used to be a minor education mode questioned by the public, but now it has turned out to be a symbol of higher education internationalization. Undoubtedly, it needs time for CFCRS to be gradually understood and accepted by the public. This change not only took place in provinces like Heilongjiang, Shanghai, Beijing and Shandong, where CFCRS has already reached a large scale, but also could be found in provinces like Yunnan and Guizhou where CFCRS is still underdeveloped. A good example is that in 2016 all the 63 CFCRS programs in Shandong province recruited students with scores above the admission scores line set for the first-tier universities. [8] Another typical example goes to Yunnan University of Finance and Economics (YUFE) in Yunnan Province. In 2000, the CFCRS programs in YUFE could only recruit students who failed in the college entrance exam, but now YUFE can recruit students whose score exceeded the second-tier college admission line by 20-30 points. All these evidences have shown that CFCRS is no more a subordinate choice of the students and their parents; it has become a popular and worthy choice for them.

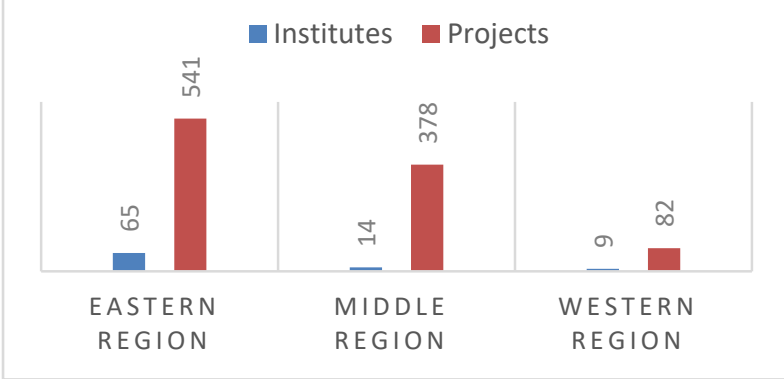

Data resources: $h t t p: / / w w w . c r s . j s j . e d u . c n$

Fig. 2. Distribution of cfcrs in the eastern, middle and western regions

\section{EXISTING PROBLEMS}

New things are always accompanied by problems and challenges, and so be the CFCRS. Through more than 30 years of development, a series of problems of CFCRS were gradually exposed, such as arbitrary charges, out-of-quota enrollment and other problems. However, the following two problems are the most prominent ones and will hinder the healthy and sustainable development of CFCRS.

First, the disciplinary and geographical imbalance of CFCRS. In terms of the discipline distribution, according to the official statistics, $26 \%$ of the Chinese-foreign Cooperativerunning programs at bachelor level or above are related to the discipline of management by the end of 2016[9]. On the contrast, the high-tech related majors, such as aerospace, new energy, new materials, cyberspace security and other disciplines which are urgently needed by the country are extremely rare. This phenomenon shows that the disciplinary distribution does not match the demand of national development. As for the geographical distribution of the CFCRS, the imbalance is even more prominent. By July 2018, in terms of Chinese-foreign Cooperative-running Programs, the number of programs in the eastern region is six times as large as that in the western region, while, in terms of the Chinese-foreign Cooperative-running Institutes, the number of institutes in the eastern region is seven times as high as that in the western region (refer to figure 2). Moreover, there are three provinces and regions in the west part of China, namely Qinghai, Ningxia and Tibet, still do not have any Chineseforeign Cooperative-running Programs or Institutes. [10] The above imbalances have been long noticed by the government and scholars, and it can be predicted that the Chinese government shall take more efforts to solve these problems during transforming period of New Era.

Secondly, although most of the Chinese-foreign Cooperative-running programs or Institutes are attractive for the students, some of them lack competitiveness. The main reason behind this is that some Chinese university failed to cooperate with prestigious universities, or introduce preponderant disciplines, advanced quality assurance systems, enough distinguished foreign teachers or other excellent educational resources. Take the cooperation between Chinese universities and Russian universities as an example, there are over 60 Russian universities held Chinese-foreign cooperatively-run programs or institutes in China. However, according to a world-recognized ranking list in 2017, only 3 of them were listed as top 10 universities in Russia. [11] Moreover, few foreign universities adopted "chain stores expansion mode" duplicating large number of similar cooperative programs with different Chinese partners in order to lower the cost and maximize the economic benefits. Such kind of programs or institutes definitely failed to achieve the common goal of CFCRS--introducing excellent foreign education resources and are questioned by the society. Therefore, they are facing severe competitive pressure and danger of vicious competitions.

\section{FUTURE PROSPECTS}

In the context of the "New Era", the educational authorities and universities shall take concrete steps to tackle the above problems to ensure sustainable and healthy development. On one hand, the educational authorities will properly control the development pace and optimize the structure of CFCRS. On the other hand, educational authorities and universities will improve the competitiveness of some of the CFCRS by upgrading the existing cooperation or highlighting their uniqueness.

Although the overall scale of CFCRS is still unable to fully meet the social demands for advanced foreign education, it is necessary to properly control the development pace, and more importantly, optimize the structure. The success of structural readjustment relies on the following two aspects. First, educational authorities and local government should provide more support and better services for the universities in the 
west to carry out CFCRS. These supports and services may include simplified application procedures, favorable policies, necessary facilities, competitive initial funding and information. Second, the educational authorities should encourage and facilitate Chinese universities to set up joint programs which are fitted for the national development demand. The possible steps may include providing dynamic discipline guidelines and assign the priority for each discipline listed. Universities should get different facilitations or support according to the priority of the joint program.

In regard to improving the competitiveness of some of the programs or institutes, there are two ways. In the long term, the educational authorities shall enhance the quality assessment system and procedures to filter out the unqualified programs or institutes. This will urge the universities from both sides to improve the cooperation by regulating the cooperation in accordance with the requirements listed in the Regulations of the People's Republic of China on ChineseForeign Cooperation in Running Schools, putting more attention and excellent educational elements into the programs or institutes. To some extreme, this will also force the universities from both sides to take serious consideration of replacing the current partner with a better one. In the short run, the programs and institutes should demonstrate their uniqueness to increase the attractiveness for the students. Localization and differentiation is a good way to do so. The universities from both sides should fit the international education elements into unique social and economic conditions of the region when designing and managing the Institutes or programs. The recommended aspects of diversification include the openness and flexibility in guiding ideology, innovative modes of running the program or institute, carefully selected disciplines or majors, new method of admission or teaching. There are numerous of good practices of localization and diversification to learn from. New York University Shanghai breaks the boundaries between different disciplines and emphasizes general education. Wenzhou-Kean University not only emphasizes the collaborative innovation among industry, university and the research center, but also actively serves the local economic development. Duke Kunshan University innovates its school-running concept and adopted a strategy of "been small and been elite".

\section{CONCLUSION}

After three decades of development, CFCRS now has become one important section of Chinese higher education in terms of the scale and influence. CFCRS have established a comprehensive administrative and quality control mechanism at the national level, expanded steadily in $90 \%$ of the provinces and regions in China, and won the recognition of the authorities and society. In the New Era, China will be more actively involved in global cooperation and CFCRS will as always pioneer the higher education internationalization of China. In the following year, the educational authorities will make efforts to cope with the problems of disciplinary and geographical imbalance and low competitiveness of some CFCRS to ensure sustainable and healthy development.

\section{ACKNOWLEDGMENT}

Our deepest gratitude goes first to Prof. Wang Rongdan for his guidance and suggestions. We also would like to thank those who helped us in completing this paper, especially the anonymous peer viewers.

\section{REFERENCES}

[1] The State Council, "General Plan of the Promotion and Construction of World-Class Universities and First-Class Disciplines,”2015. (In Chinese) http://www.gov.cn/xinwen/2015-11/05/content_2960898.html

[2] General Office of the CPC Central Committee, General Office of the State Council, "Certain Opinions for the Opening-up of Education in the New Era ,” 2016. (In Chinese) http://www.moe.edu.cn/jyb_xwfb/s6052/moe_838/201605/t20160503_2 41658.html

[3] The State Council, "13th Five-Year Plan for the Development of National Education,”2017. (In Chinese) http://www.moe.gov.cn/jyb_xxgk/moe_1777/moe_1778/201701/t20170 119_295319.html

[4] Huang Jinluke, "Further reform of Chinese-foreign cooperation in running schools,” Chinese Education Newspaper, March 23, 2018 (6). (In Chinese)

[5] Ministry of Education, "Chinese-foreign cooperative programs and schools reviewed and approved by the Ministry of Education in 2018," http://www.crs.jsj.edu.cn/index/sort/1006. (In Chinese)

[6] Lin Jinhui, "On scale, quality and effects in Chinese-foreign cooperation in running schools and the relationships,” Educational Research, 2016(7) pp. 39-43. (In Chinese)

[7] Ministry of Education, "The quality of Chinese-foreign cooperation in running schools promotes steadily,” (In Chinese)

http://www.moe.gov.cn/jyb_xwfb/s5989/s6635/201603/t20160323_2348 61.html.

[8] Zang Xuping, "Chinese-foreign cooperation in running schools becomes favorite in China,” Qingdao Morning Daily, Aug 9, 2016 (4). (In Chinese)

[9] http://zj.people.com.cn/n2/2017/1207/c18632731004934.html?from=groupmessage\&isappinstalled $=0$ (In Chinese)

[10] Guo Qiang, “The thinking on Chinese-foreign cooperation in running higher education under the perspective of B\&R,” Journal of Higher Education Management, Nov. 2017 (7). (In Chinese)

[11] Guo Qiang, ““New era”: the Logic and Prospective of Chinese-Foreign Cooperation Running Schools Development," Conference Proceedings of the 9th Annual Meeting on CFCRS, Sep. 2018,pp102-113 (In Chinese) 